University of Nebraska - Lincoln

DigitalCommons@University of Nebraska - Lincoln

Textile Society of America Symposium

Proceedings

$10-2020$

\title{
Prejudiced Commodities: Understanding Knowledge Transfer from India to Britain through Printed and Painted Calicoes, 1720-1780
}

Aditi Khare

Follow this and additional works at: https://digitalcommons.unl.edu/tsaconf

Part of the Art and Materials Conservation Commons, Art Practice Commons, Fashion Design Commons, Fiber, Textile, and Weaving Arts Commons, Fine Arts Commons, and the Museum Studies Commons

This Article is brought to you for free and open access by the Textile Society of America at DigitalCommons@University of Nebraska - Lincoln. It has been accepted for inclusion in Textile Society of America Symposium Proceedings by an authorized administrator of DigitalCommons@University of Nebraska - Lincoln. 


\title{
Prejudiced Commodities: Understanding Knowledge Transfer from India to Britain through Printed and Painted Calicoes, 1720-1780. ${ }^{1}$
}

\author{
Aditi Khare \\ akhare1@ualberta.ca
}

Captivating consumers and manufacturers with colours that were vibrant and fixed, early modern chintz was a vehicle of taste, visual culture, manufacturing techniques, and material innovation. By the mid-eighteenth century, the imported textiles faced serious competition from domestic printed cottons in Europe, especially since the British calico industry had emulated and innovated despite the prohibitions on manufacturing calico. Britain's transition from a consumer market with a nascent cotton printing industry to a leading global exporter was hardly straightforward. It was characterised with global exchange, political debate, mercantile and economic interest, and technical development. This paper focuses on the manufacturing perspective of printed calico during this transition, and the role played by useful knowledge assembled through trade and exchange. It argues that the artisanal knowledge accumulated from India through trade, exchange, and other forms of tacit learning in the seventeenth and eighteenth centuries was highly instrumental in the development of the European cotton printing industry. Since calico was primarily popular due to the vibrant and fast colours, the chemistry of the dyes and mordants (fixing chemicals) responsible for these colours formed a crucial factor in the manufacture and development. However, the wide chronological, thematic, and inter-disciplinary expanse of the subject of calico printing and painting has hitherto obstructed dedicated studies on technique and skill. Within such extensive paradigms, the chemical knowledge of prescriptive processes in the eighteenth century plays a key role on local and global levels. As we shall see, dissemination of this knowledge was possible partly due to trade and travel, aided by institutional, political and industrial interest. It was an example of a transition in society's treatment and organisation of knowledge - from fragmentary additions to the epistemic base to centralised knowledge networks.

An understanding of development of knowledge beyond an abstract concept is essential for the purpose of this paper. While the knowledge responsible for calico printing and painting has been analysed in several ways, a slightly more tangible framework can aid our analysis by identifying forms of knowledge manifested in the primary and secondary sources, as well as their networks of dissemination. Joel Mokyr provided historians with a set of much debated definitions pertaining to useful knowledge. ${ }^{2}$ Useful knowledge, as perceived by Mokyr and later expanded upon by Perez and others, is knowledge of natural phenomenon which can be observed, experimented with and refined. This knowledge, he hypothesises, only exists when it is transferred by carriers - living or otherwise. ${ }^{3}$ Thus in the case of calico printing, knowledge of cotton, dyes and mordants - and the means through which they

\footnotetext{
${ }^{1}$ This paper is largely based on my MA thesis (2019) for the Victoria and Albert Museum/ Royal College of Art History of Design Program.

${ }^{2}$ Joel Mokyr, The Gifts of Athena: Historical Origins of the Knowledge Economy, (Princeton: Princeton University Press, 2002).

${ }^{3}$ Mokyr, Gifts of Athena, 3.
} 
interact - would count as useful knowledge. He further divides this rather large superset into prescriptive and propositional knowledge. ${ }^{4}$ Propositional knowledge is defined as the knowledge that forms the epistemic base around any kind of technology or material in a society. It is considered collective, although Epstein suggested that this base is often present among the intellectual and social elite. ${ }^{5}$ In the case of knowledge about calico printing, propositional knowledge pertains to the understanding of cotton, chemicals, and the designs of the finished textiles. Luiten and van Zanden have argued that propositional knowledge alone would be useless if it was not visible in the form of applications. ${ }^{6}$ This application and the instructions on how to achieve it are what Mokyr categorises as prescriptive knowledge. Simply put, propositional knowledge is the answer to the questions of 'what' whereas prescriptive knowledge is instructional and the answer to questions of 'how'.

The academic literature surrounding trade and exchange of calico fabrics is both extensive and multi-faceted. Several economic, textile, global and cultural historians have researched the eighteenth-century trade in calicoes, highlighting import blending, Europe's familiarisation and adaptation of calicoes, the transfer of visual language, and the development of Europe's manufacturing expertise in the past few decades. From a more conceptual perspective, the subject is also associated with the benefits of free trade vis. mercantilism, the chemical revolution, and colonial agency.

Mokyr's work has been seminal in giving shape to this literature by defining the knowledge and its supersets responsible for the European Enlightenment and industrial revolution. This discussion is a part of debates surrounding the 'great divergence' of Europe and Asia around the eighteenth century, which has challenged Eurocentric assessments of the industrial revolution. The work of earlier scholars such as Chapman and Chassagne, Floud and Irwin focuses on individual European developments as events that led to the industrial revolution and have been compiled from the textile historians or curator's point of view. In the past few decades, discussion around global histories has shifted from the Eurocentric, invention-based approach to the more comparative, gradual widening of epistemic bases of knowledge which focuses instead on networks and exchange. Mokyr thus builds on research by Pomeranz, Abu-Lughod, and Landes. ${ }^{8}$

The superset of the term useful knowledge has been extended to include tacit, artisanal, incidental and experiential knowledge. Riello and Pérez have insisted on the inclusion of artisanal tacit knowledge within the umbrella of useful knowledge. This is especially important in the case of textile trade, as much of the manufacturing in India was done within craft based industries through oral traditions rather than factory based production. ${ }^{9}$ Arguing for the importance of craft development, Epstein insists that the anonymous craftsman in the

\footnotetext{
${ }^{4}$ Mokyr, Gifts of Athena, 9.

${ }^{5}$ S.R. Epstein, 'Transfer of Technical Knowledge and Innovating in Europe', in Technology, Skills and the PreModern Economy in the East and the West, eds. Maarten Prak, Jan Luiten van Zanden, (Leiden: Brill, 2013 ), 64. ${ }^{6}$ Prak, van Zanden, Technology, Skills, 5.

${ }^{7}$ Mokyr, Gifts of Athena, 9.

${ }^{8}$ Janet Abu-Lughod, Before European Hegemony: The World System A.D. 1250-1350, (Oxford: Oxford University Press, 1991); David S. Landes, The Wealth and Poverty of Nations: Why Some Are So Rich and Some So Poor, (New York: Little, Brown, 1998); Kenneth Pomeranz, The Great Divergence: China, Europe, and the Making of the Modern World Economy, (Princeton: Princeton University Press, 2001).

${ }^{9}$ Tirthankar Roy, 'Knowledge and Divergence from the Perspective of Early Modern India,' Journal of Global History, Vol.3, (2008), 374.
} 
early modern society was perhaps the most important source of incremental innovation. ${ }^{10}$ Prak and van Zanden have also commented on the validity of experiential craft-based knowledge as useful knowledge. Based on their approach, artisans assume the role of producers of knowledge whereas their products become carriers of the same. ${ }^{11}$

Useful knowledge regarding calico printing has been analysed to some extent in the past few years. Riello's concept of the 'Indian Apprenticeship' forms a structure for the transfer of knowledge on calico trade and Gottmann's work on global trade has analysed the networks of codified and tacit knowledge transfer in France. ${ }^{12}$ As Riello proposes, the trade was an apprenticeship in four aspects - material, technique, taste and design - for European trading companies and manufacturers. ${ }^{13}$ For this paper, the transfer of knowledge through trade would comprise of knowledge about all four aspects.

The material apprenticeship comprised of familiarisation with cotton as a textile material and dyes as chemical objects used to achieve colours. While Riello focuses on the familiarisation with cotton, there seems to be a gap in scholarship regarding the familiarisation with dyes. ${ }^{14}$ Schwartz and Irwin have mentioned linen printing practiced in Europe prior to trade with India, but these colours were not fixed. ${ }^{15}$ It is possible to see a transition in the information surrounding the dyes and mordants in printing, i.e., the chemical developments in printing. To some extent, Nieto-Galan and Fox's work has analysed the evolving expertise in chemical knowledge of calico printing and the role of practitioners as experts. ${ }^{16}$ This development in the chemical knowledge of calico printing falls in the propositional category and can be seen as a widening of the epistemic base in Britain.

The second part of the apprenticeship revolved around design and technique. This is primarily the category wherein most of the transfer of knowledge falls. The techniques and chemical processes can be analysed through chemists and practitioners' accounts and have been researched to a small extent. The design vocabulary and its hybridisation has been studied through surviving fabric samples, printing blocks, pattern books, and East India Company (EIC) instructions. Styles and Irwin have used surviving fabrics to establish the idea of a linear transition, wherein the European design aesthetic was imitated by Indian manufacturers ${ }^{17}$. However, an increasing volume of texts challenges this approach, arguing

\footnotetext{
${ }^{10}$ Prak, van Zanden, 'Introduction: Technology, Skills and the Pre-Modern Economy in the East and the West', Technology, Skills, 5.

${ }^{11}$ Prak and van Zanden, 'Introduction,' 8.

${ }^{12}$ Felicia Gottmann, Global Trade, Smuggling, and the Making of Economic Liberalism: Asian Textiles in France 1680-1760, (New York: Palgrave Macmillan, 2016).

${ }^{13}$ Giorgio Riello, 'The Indian Apprenticeship: The Trade of Indian Textiles and the Making of European Cottons.' How India Clothed the World: The World of South Asian Textiles, 1500-1800. Eds. Giorgio Riello, Tirthankar Roy (Leiden: Brill, 2009), 313.

${ }^{14}$ Giorgio Riello, 'Asian Knowledge and the Development of Calico Printing in Europe in the seventeenth and eighteenth centuries,' Journal of Global History, vol. 5, (2010), 5-6.

15 John Styles, The Dress of the People: Everyday Fashion in Eighteenth-century England (Yale: Yale University Press, 2007); John Irwin and R. Schwartz, Studies in Indo-European Textile History, (Calico Museum of Textile, 1966).

${ }^{16}$ Robert Fox, Agusti Nieto-Galan (eds.) Natural Dyestuffs and Industrial Culture in Europe, 1750-1880, (Massachusetts: Science and History Publications, 1999).

${ }^{17}$ John Irwin, 'Origins of the Oriental Style in English Decorative Art,' The Burlington Magazine. vol. 97, (April 1955) 109; John Styles, 'Indian Cottons and European Fashion, 1400-1800,' and Prasannan Parthasarathi's response in Global Design History, eds. Giorgio Riello, Sarah Teasley and Glenn Adamson, (London: Taylor and Francis, 2011), 42.
} 
for a mutual adaptation, where the fabrics incorporated the design language of both cultures. ${ }^{18}$

Chapman, Floud, and Chassagne have analysed the development of these skills, but their analysis studies individual inventions rather than transitions. Their work is remarkably useful in taking scope of early modern primary sources and for quantitative analysis. ${ }^{19}$ Floud has especially been highly instrumental in setting up the trajectory of calico printing in Europe. ${ }^{20}$ However, as with other textile research in the mid-twentieth century, the trajectory of the calico printing industry here is seen as a collection of individual events of invention rather than small increments in the collective prescriptive knowledge of the manufacturers and consumers. This paper fits into the methodology adopted by more recent literature, wherein the development of the industry is seen as a set of small increments aiding the development instead of 'hero' moments in innovation.

The last category in the apprenticeship is that of taste, or what has been termed as the 'Calico Craze'. ${ }^{21}$ There are several debates surrounding the term calico craze and the nature of Europe's fascination with calico textiles. Lemiré, Styles, Riello, and Parthasarathi have established that the nature of consumption of calico textiles may have started out as a fascination but was largely a slow process encouraged by mercantilist policies, import substitution, market curation and consumer preferences. ${ }^{22}$ The analysis of tangible transfers of knowledge can be developed further. The subject of this research is relevant not only to the debates surrounding knowledge exchange and dissemination, but also the development of manufacturing systems and industry.

\section{Technique and Science: Understanding the process}

The greatest reason for the popularity of painted and printed calico fabrics in Britain was the wide variety of fast colours which they exhibited. ${ }^{23}$ The practice of printing or painting on fabric was prevalent in Europe prior to the introduction of Indian calico, often being executed on linen and wool in single colours. The technique of oil painting was transferred from paper onto fabric, and although executed in single colours which would not stand the test of

\footnotetext{
${ }^{18}$ Giorgio Riello, Cotton: The Fabric that made the Modern World. (Cambridge: Cambridge University Press, 2015), 100; Beverly Lemiré, 'Revisiting the Historical Narrative: India, Europe and the Cotton Trade, 13001800', The Spinning World: A Global History of Cotton Textiles, 1200-1850. Eds. Giorgio Riello, Prasannan Parthasarathi. (Oxford: Oxford University Press, 2009), 215.

${ }^{19}$ Stanley D. Chapman, 'The Textile Factory Before Arkwright: A Typology of Factory Development,' The Business History Review, vol. 48, (Harvard 1974), 451 - 478; S.D. Chapman, S. Chassagne, European Textile Printers in the Eighteenth Century: A Study of Peel and Oberkampf, (London: Heinemann Educational: Pasold Fund, 1981).

${ }^{20}$ C. Floud, 'The English Contribution to the Development of Copper Plate Printing,' Journal of the Society of Dyers and Colourists, (July 1960); 'The Origins of English Calico Printing,' Journal of the Society of Dyers and Colourists (June 1960), 'The English Contribution to the Early History of Indigo Printing' Journal of the Society of Dyers and Colourists, (June 1960).

${ }^{21}$ Beverly Lemiré, Fashion's Favourite: The Cotton Trade and the Consumer in Britain, 1660-1800, (Oxford: Oxford Univeristy Press, 1991).

${ }^{22}$ Riello has written extensively on the topic: see Giorgio Riello, 'The Globalization of Cotton Textiles: Indian Cotton, Europe and the Atlantic World, 1600-1850,' Giorgio Riello and Prasannan Parthasarathi (Eds.), The Spinning World: A Global History of Cotton Textiles, 1200-1850 (Oxford: Oxford University Press, 2009), 261-87; Riello, 'Asian Knowledge'; Giorgio Riello, 'The Rise of Calico Printing in Europe and the Influence of Asia in the Seventeenth and Eighteenth Centuries', unpublished paper, http://www.lse.ac.uk/EconomicHistory/Assets/Documents/Research/GEHN/LesTreilles/PUNERiello.pdf [accessed 25 May 2018]; Riello, Cotton.

${ }^{23}$ John Ovington, A Voyage to Surat in the Year 1689, ed. H.G. Rawlingson (London: 1929), 167; quoted in Riello, 'The Rise of Calico Printing,' 9.
} 
washing with soap and water, this was nevertheless an effective method for decorating some fabrics. ${ }^{24}$ The fastness of the colours on cotton challenged this practice - an advantage which was a result of several factors such as mordant printing, properties of cotton as the receiving surface, qualities achieved by colouring with indigo, madder and cochineal. ${ }^{25} \mathrm{~A}$ basic understanding of some processes will help us understand these developments.

Painted or printed fabric can be produced using several methods involving dyes, mordants, thickeners etc. The choice of method usually depended on the feasibility, materials available, nature of colouring pigment and details required within the design. The traditionally practiced method in India involved mordant printing, wherein the mordant was first painted onto the fabric in varying strengths or combinations based on the result required and the chemical affinity of the dye. ${ }^{26}$ Mordants react with the dyes in order to form an insoluble colouring substance which then sticks to the fabric and thus the colour is fixed. ${ }^{27}$ Hence, for varying shades of the same colour, the mordant solution was painted onto the fabric in varying concentrations. A larger concentration of mordant would generally result in a darker shade of the same dye, and different mordants would react with different pigments to achieve various colours. ${ }^{28}$ Once the mordants were all painted onto the fabric, it would then be dipped into a vat containing the dye solution, and would take on varying colours. This process was commonly used for madder dyeing, as madder can achieve a wide range of colours.

Another common process of printing involved wax-resist. Implemented in order to produce goods wherein the ground was coloured and the pattern was white, this process involved applying wax or other resist material on the pattern - which would prevent the covered areas from getting dyed. The cloth could then be dipped in a dye vat, resulting in a coloured ground and a white pattern where the resist was applied. Understandably, this process required a cold or tepid dye vat, in order to prevent the resist from melting while in the vat. ${ }^{29}$ It was used often in indigo printing, as indigo dye requires separate processes from usual pigments.

The differences in calico printing between Europe and Asia were often based on understanding of dyes, cotton fabric as opposed to wool or silk, and the technical properties of the available materials such as mordants. In order to comprehend the difficulties European printers faced when adopting the painted and printed calicoes as a manufactured commodity, a brief look at each of these factors is required.

Fabric: Several scholars have theorized that the initial difficulty with printing on cotton in Europe was primarily due to the unfamiliarity of cotton as a fabric. Traditionally, wool and silk were more commonly available and decorated for various purposes. ${ }^{30}$ However, the unfamiliarity with cotton was not only cultural but also scientific. Cotton is a plant fiber as opposed to silk or wool, which are animal fibers. Structurally, the animal fibers possess a higher tendency to retain colouring matter after being treated to remove their glutinous coating and hence making them less resistant to colour. In comparison, cotton required an

\footnotetext{
${ }^{24}$ Ada K. Longfield, 'History of the Irish Linen and Cotton Printing Industry in the 18th Century,' The Journal of the Royal Society of Antiquaries of Ireland, vol. 7, No. 1, (Jun. 30, 1937), 26.

${ }^{25}$ Lemiré, Fashion's Favourite, 18.

${ }^{26}$ Floud, 'Early History of Indigo Printing,' 345.

${ }^{27}$ Capey, The Printing of Textiles, 87.

${ }^{28}$ Capey, 88.

${ }^{29}$ Floud, 'Early History of Indigo Printing,' 345.

${ }^{30}$ Riello, 'Asian Knowledge,' 16.
} 
additional step of treating it with acid before proceeding with the printing. ${ }^{31}$ In theory, the colouring matter will be retained in the fabric as opposed to dissolving in water if its adhesion with the fiber is more compared to its adhesion with the water. We must recognize that the scientific propositional knowledge concerning cotton, although a factor in implementation, was perhaps neither a concern nor a query for the manufacturers during the initial acclimatization of cotton in Europe. It was due to the continuous process of refinement and experimentation in that the scientific knowledge regarding fibers was analysed in greater depth.

Mordants: In the case of colouring matter which adheres to water and dissolves instead of being retained on fabric, mordants are required to react with the colouring matter and essentially create an insoluble colour precipitate which will then be retained by the fabric. ${ }^{32}$ Mordants themselves usually possess no colour, and were used in wool, silk and cotton printing. Their use was not an Asian introduction into the manufacturing process. However, it is important to note that basic and direct mordants usually sufficed for printing on wool and silk, requiring a shorter and simpler process to form a basic salt on the fiber. ${ }^{33}$ In the case of cotton, combination of different processes such as addition of acids or steam to the mordants was required to achieve fast colours. ${ }^{34}$ Further, the application of mordants largely depended on the nature of the dye.

Madder dye and Turkey red: Madder was a vegetable dye used for printing 'alizarin' dye combined with the iron mordant alum. ${ }^{35}$ The term madder dye or madder print was often used to describe both the dye itself and the style of mordant printing - which was primarily the manner in which Turkey red fabrics were printed in both India and the Levant. ${ }^{36}$ The dye itself imparts various shades of red when mixed with different concentrations of aluminous mordants, black and purple with different concentrations of iron mordants, and an orange when mixed with a separate dyestuff and aluminous mordant. ${ }^{37}$ Due to the varied applications of the dye and the style of printing, madder was employed in printing both wool and cotton across India, Turkey and Europe. However, it has been suggested that the introduction of the process wherein a single dip could produce several shades on cotton was one of the factors responsible for the spread of the technique in Europe during the eighteenth century. ${ }^{38}$ This technique was also termed as 'turkey red', and was the cause of extensive transfer of both tacit knowledge through skilled craftsmen and espionage from Turkey through Europe, as well as codified transfer through manuals, trade secrets, experiments etc. ${ }^{39}$

Indigo printing: Indigo is a vegetable dye that occurs in an insoluble state. Due to the natural insolubility, indigo required an additional stage of reducing it to a soluble compound called indigo white. Once the indigo white compound would combine with the cloth, it could be exposed to air, thus allowing for re-oxidation and the blue colour. ${ }^{40}$ The additional stage meant that it could not be printed through the usual processes, as indigo white would

\footnotetext{
${ }^{31}$ Edward Bancroft, Experimental Researches Concerning the Philosophy of Permanent Colours, and the Best Means of Producing them by Dyeing, Calico Printing etc (London: 1794), 109.

${ }^{32}$ Capey, Printing of Textiles, 60.

${ }^{33}$ Turnbull, A History of the Calico Printing Industry, 18.

${ }^{34}$ Capey, Printing of Textiles, 61.

${ }^{35}$ Capey, 89.

${ }^{36}$ Riello, 'Asian Knowledge', 22.

${ }^{37}$ Parnell, Dyeing and Calico Printing, 140.

${ }^{38}$ Parnell, 136.

${ }^{39}$ Riello, 'Asian Knowledge', 22.

${ }^{40}$ Bancroft, Experimental Researches, 170-171.
} 
immediately oxidize into insoluble indigo as soon as it came in contact with air on the brush or block - and would not transfer to the fabric. Due to this property it would nearly always be printed through the resist printing process wherein the pattern could remain white under wax or fat resist and the ground would be dyed with indigo. ${ }^{41}$ The introduction of indigo in Europe was on account of transfer of both prescriptive and propositional knowledge. The acclimatization with indigo as a dye was propositional, and the resist printing process that indigo required was prescriptive. The transition and refinement of indigo printing was also an example of adoption of manufacturing knowledge and later experimentation leading to innovations based on this primary knowledge. Prior to the addition of indigo to Europe's epistemic base, European fabrics employed woad for printing blue. This product could only be dyed in hot vats, but the hot vats could not be employed in indigo resist printing as the wax resist would melt at higher temperatures. ${ }^{42}$ Thus the introduction of indigo facilitated refinement in the wax-resist method, allowing for a tepid or cold vat dyeing - and better resist patterns. Further refinement in the printing process was the development of patterns with white ground and blue design. As we now understand, the immediate oxidization of the indigo white meant it could not be printed through blocks or painted via brushes. This problem was solved by adding orpiment (arsenic trisulphide), gum and thickener to the solution of indigo white and delaying the oxidation process enough to allow for it to be painted onto the fabric. Floud suggests that although this process was not feasible for mass production due to the poisonous nature of orpiment, it was nevertheless an indispensable link in the development of indigo printing from the resist technique to the eventual mechanical developments which allowed for indigo to be block printed. ${ }^{43}$

\section{Calico Acts and their role in Knowledge Transfer: A comparison.}

The consequences of the Calico acts on the development of the calico printing industries of various European states were not homogenous or simplistic. The different decades in which Britain and France implemented and repealed these acts, and the extent to which the acts banned the consumption and manufacture of calico had implications on the strategies of the respective trading companies and the knowledge collected by them. Britain implemented its prohibition acts in 1700 and 1721 and repealed them in 1774. France implemented them slightly earlier in 1686 and repealed them in $1759 .{ }^{44}$ These acts first prohibited the consumption of calico in Britain and France, and later prohibited both consumption and manufacture of printed cotton unless it was for the purpose of re-export. The campaigning and debate surrounding these acts in both countries led to a public discussion including manufacturers, traders, and politicians regarding the industry and the economy for many decades.

Chaudhuri suggests that 'the English and British prohibition laws enacted in the early part of the eighteenth century and directed against the wearing of cotton materials probably also discouraged any idea of importing technical knowledge from abroad. ${ }^{45}$ This conclusion was likely true only to some extent. The company records after 1721 contain drastically fewer references to chintz (printed calicoes), and instead show a rise in import of plain white calicoes into Britain. For instance, the council in London instructed the factors at Surat in 1743 , 'we absolutely forbid you, buying any sorts of chints, those received for several years

\footnotetext{
${ }^{41}$ Parnell, Dyeing and Calico Printing, 178.

42 Floud, 'Early History of Indigo Printing', 345.

${ }^{43}$ Floud, 346-347.

${ }^{44}$ Lemiré, Fashion's Favourite, 29.

${ }^{45}$ K.N. Chaudhuri, The Trading World of Asia and the East India Company, 1660-1760. (Cambridge: Cambridge University Press, 2006), 239.
} 
past having sold at a very great loss. ${ }^{46}$ Apart from the lack of imports, the prohibitions could have also been responsible for some lack of codified knowledge. Schwartz hypothesises that the men of science interested in the art of printing durable colours on cotton would have been hesitant about getting any information published due to the calico acts. ${ }^{47}$ If this was indeed a contributing factor, the English East India Company (EEIC) servants would have been further reluctant about publishing material related to the banned imports due to their personal associations with the administration. However, these arguments stand in contrast to the French politics surrounding the prohibition acts. While the prohibition in France was more restrictive than that in Britain, the debate surrounding the repeal of these acts in 1759 generated discussion surrounding free trade and economic liberalism. In order to prove that France would be able to sustain its calico industry in face of competition from Asian fabrics should the act be repealed, the stakeholders arguing for free trade and liberalism took concentrated measures to equip their industry and state with manufacturing knowledge. ${ }^{48}$ The institution largely instrumental in this process was the Bureau du Commerce, an institutional body responsible for manufacture and manufacturing knowledge. The Bureau was comprised of academics, experts and researchers, politicians, and inspectors of commerce whose role shifted from implementing prohibition laws to performing as the connecting link between the Bureau and the manufacturers, in order to collect information. ${ }^{49}$ The bureau, its associated members, and other prominent stakeholders were responsible for accumulating codified knowledge and tacit expertise in calico printing. They implemented industrial espionage, funded centres of manufacture, accumulation of codified knowledge and skilled migration.

In France the prominence accorded to collection of manufacturing knowledge was aimed at emulation - defined as the desire to surpass other's achievements through imitation. ${ }^{50}$ This virtue has been recently recognised as a characteristic of eighteenth century France, and in the case of calico printing, was defined by many liberalists as the effort to surpass the development of other European cotton industries by imitating their strategies and skills. ${ }^{51}$ Much like import substitution, emulation was a tool adopted by European industries to imitate the techniques practiced in other countries in order to make superior products. On the highly competitive stage of eighteenth-century overseas trade, it is probable that most French organisations practiced emulation or other forms of rivalry and thus actively participated in measures to improve technical knowledge.

The establishment of the EIC(s) had much to do with the mercantilist ideology of economy, both in England and France. Mercantilist ideology was based on the idea that value could only be finite, and existed in the form of land and its products. ${ }^{52}$ Essentially, this meant that since wealth was finite, it could not be generated by human labor and international trade was only profitable if it resulted in expansion and monopoly directed towards increasing the wealth of the nation as a whole. ${ }^{53}$ The mercantilist ideology argued for international trade to be focused towards expansion - bringing in wealth to the nation in the form of land and its

\footnotetext{
${ }^{46}$ British Library (BL), Miscellaneous Factory Records, IOR/G/40/7A.

${ }^{47}$ P.R. Schwartz, 'French Documents on Indian Cotton Painting, 1: the Beaulieu ms, c. 1734,' Journal of Indian Textile History (Vol 2, 1956).

${ }^{48}$ Gottmann, Global Trade, 132.

${ }^{49}$ Gottmann, 108.

${ }^{50}$ John Shovlin, 'Emulation in Eighteenth-Century French Economic Thought,'Eighteenth-Century Studies, vol. 36, No. 2, (Winter 2003), 224.

${ }^{51}$ Gottmann, Global Trade, 106.

${ }^{52}$ Steve Pincus, 'Rethinking Mercantilism: Political Economy, the British Empire, and the Atlantic World in the Seventeenth and Eighteenth Centuries', The William and Mary Quarterly, vol. 69, No. 1, (January 2012), 12.

${ }^{53}$ Pincus, 'Rethinking Mercantilism,' 18.
} 
products - or towards monetary gain wherein only product based trade was profitable if it brought bullion into the country. From the point of view of mercantilist theory, calico was not a profitable trade unless it could be re-exported - it was seen as a drain on the economy where bullion left the country and could not be recovered since human labor was supposedly worthless. This monopolistic ideal was also partly responsible for the overseas trade rivalry between companies from different nations. Throughout a period of several wars within Europe, overseas trade was viewed initially as an extension of the dynastic struggles in Europe and later as an important strategic and commercial battleground. Several historians have termed international trade in the seventeenth and eighteenth centuries as a 'zero-sumgame', wherein one country could only gain wealth at the cost of the other countries' loss. ${ }^{54}$ Since mercantilism views wealth only in terms of land or bullion, the finite resources available for accession in overseas trade could only be added to any one country's wealth if other countries did not gain the same. Similarly, re-export would simultaneously bring in bullion and drain another country's money, ridding the exporter of a product which had been imported at the cost of bullion drain. This mercantilist argument was often used to promote greater overseas trade for re-export and military expansion. The same campaign was also against importing manufactured products - since they led to bullion drain from the country and brought in nothing that could be categorized as wealth. The policies of the EEIC in particular were condemned as adding to individual gain of the company factors and not to the collective wealth of the nation. ${ }^{55}$

During the latter part of the public debate on economic policies and national wealth, i.e., mideighteenth century, the mercantilist argument was countered by the liberal argument wherein wealth was believed to be infinite and increased by human labour. Value was no longer given to just land and agricultural products, but also manufactures made through human labour. Since they valued human labour as a source of wealth, manufactures and manufacturing knowledge could be given priority. ${ }^{56}$ In the latter part of the debate surrounding calico trade, the economic liberal policy took a greater stand in France. ${ }^{57}$ In Britain, the general political climate remained inclined towards the expansionist mercantilist ideologies, and manufacturing knowledge was largely at odds with mercantilist ideals. In the zero-sum-game of international trade therefore, it would be understandable to assume that the EEIC was not intent on collecting manufacturing knowledge after the implementation of the calico acts.

However, in France, the manufacturing ideology was used to ally with and promote the mercantilist cause. Hilaire-Pérez and Gottmann have analysed how the French state adopted a collective approach to innovation and technical expertise, as opposed to the more individualistic enterprising approach in Britain. ${ }^{58}$ This approach in France - treating invention as collective responsibility - led to greater institutional and sponsored measures that encouraged expertise. Particularly in the case of calico, the codified and tacit knowledge regarding printing and dyeing was collected through various means, within a network of institutions, politicians, academics, experts and manufacturers. This policy increased the

\footnotetext{
${ }^{54}$ Gottmann, Global Trade, 137; see also: D.C. Coleman, 'Mercantilism Revisited,' The Historical Journal, (No. 23, Vol. 4, December 1980), 783; Pincus, 'Rethinking Mercantilism,' 12, 18; Patrick O’Brien, Trevor Griffiths, Philip Hunt, 'Political Components of the Industrial Revolution: Parliament and the English Cotton Textile Industry, 1660-1774,' The Economic History Review, (Vol. 44, No. 3, August, 1991), 403.

${ }^{55}$ Lucy S. Sutherland, The East India Company in Eighteenth Century politics, (Oxford: Clarendon Press, 1952) 26.

${ }^{56}$ Carew Reynell quoted in Pincus, 'Rethinking Mercantilism,' 20.

${ }^{57}$ Paul Bairoch and Joel Mokyr quoted in Pincus, 'Rethinking Mercantilism,' 11.

${ }^{58}$ Liliane Hilaire-Pérez, 'Technical Invention and Institutional Credit in France and Britain in the 18th century', History and Technology, an International Journal, vol. 16, issue 3, (2000), 288; Gottmann, Global Trade, 108.
} 
value attributed to 'useful knowledge' on a national level, and individuals found it more profitable to contribute to the collective useful knowledge. ${ }^{59}$

This is not to suggest that Britain did not have similar institutions or entrepreneurs. The Royal Society of Arts (RSA) in London was one of several philanthropic institutions that encouraged matters of manufacture and invention. As Pérez notes, the contrast between Britain and France was not monumental outside of the framework of the government and state. ${ }^{60}$ It was the priority and value assigned by the government in France to inventions and scientific advancement that promoted the accumulation of collective useful knowledge. Gottmann notes how this manufacture-oriented policy of the French liberals was in part developed from Colbertist and mercantilist ideals of inventions being assessed and controlled by the state in order to promote the national development. ${ }^{61}$ Hilaire-Pérez also mentions that the 'administrative collegiality and recourse to the expert' practiced by the Bureau were legacies of Colbert. ${ }^{62}$ Thus, the economic liberal cause argued for the manufacturing knowledge to empower the nation and use it to achieve mercantilist ideals. This methodology was different from the British manner of debating between manufacturing wealth and mercantile wealth - hence inferring greater value on collective useful knowledge for a few decades in eighteenth century France.

Neither Britain nor France adopted a better approach towards the development or prohibition of their calico industry. Even though Britain's policies were less stringent than France and more adaptable, the calico industry in Britain led to many inventions and cotton mechanisation - eventually becoming one of the first industries to bring forth the industrial revolution. ${ }^{63}$ However, from the perspective of knowledge accumulation and assimilation, France's prohibitions and debates eventually led to a greater value for useful knowledge, and a more intentional collective search for the same.

While the calico acts certainly had a negative impact on the codified knowledge and material consumption surrounding these textiles, it is debatable whether these acts entirely reduced or increased public and entrepreneurial interest due to the several reasons we have discussed here. The implementation of these acts also provided an incentive for the domestic products to be developed, and gave rise to what has been termed as import blending. ${ }^{64}$ The implementation of the first act in England removed the influx of foreign calicoes and created a gap in the market for local calicoes to fulfil the consumer demand - encouraging the development of the British calico industry. Even after the prohibition on manufacture in 1721, there was scope for printing of linen-cotton (fustian) fabric to allow for re-export. ${ }^{65}$ Also important was the migration of workers and artisans throughout Europe, for reasons related to religious persecution, manufacture prohibition, as well as economic prospects. These craftsmen became live carriers of embodied tacit knowledge and contributed heavily to the development of the calico printing industries.

\section{Tacit knowledge: Perspectives on the East India Company}

\footnotetext{
${ }^{59}$ Gottmann, Global Trade, 122.

${ }^{60}$ Hilaire-Pérez, 'Technical Invention,' 292.

${ }^{61}$ Gottmann, Global Trade, 108.

${ }^{62}$ Hilaire-Pérez, 'Technical Invention,' 290.

${ }^{63}$ Gottmann, Global Trade, 172.

${ }^{64}$ Prasannan Parthasarathi and Giorgio Riello, 'Introduction: Cotton textiles and Global History,' The Spinning World, 9.

${ }^{65}$ O’Brien, Griffiths, Hunt, 'Political Components,' 399.
} 
Tacit knowledge concerning calico manufacture was transferred through live carriers and their experiences, the trade products and other accounts. Many historians have questioned the extent and effectiveness of this form of knowledge carried by the EIC's men and other people present in India. The root of this doubt lies in the argument that the traders and travelers were concerned with mercantilist and economic issues rather than the art of printing or painting calicoes. As we have seen in the previous section, this was not entirely true, as with the French travelers and company officials who travelled to India to observe and record processes regarding calico printing. Looking at the company's records from the point of view of live and incidental knowledge carriers indicates an increase in Britain's epistemic base concerning calico printing and painting. When viewed from the perspective of tacit knowledge, these carriers take the form of Mokyr's and Hilaire Pérez's categories of 'practical useful knowledge', which, as Mokyr states, was 'often unsystematic and informal, passed down vertically from master to apprentice or horizontally between the agents. ${ }^{96}$ If we take into account the geographical, linguistic and motivational issues of Europeans in India in addition to the difficulties which Mokyr characterizes with live carriers, the EIC men function as carriers of propositional knowledge, although not as carries of prescriptive technical knowledge concerning printing itself.

The EEIC letter books contain several instances of instructions sent from London regarding the quality of fabrics required in England and the preferred consumer choices to be reflected in the design. ${ }^{67}$ These were largely based on the auction prices of the EIC's quarterly auctions in London and samples of fabric (musters) sent from India and would indicate the application of trade and design based knowledge acquired by the merchants within England or Europe. ${ }^{68}$ Notably this exchange of knowledge, and more specifically samples and musters, was reciprocal. The company's factors in India were regularly instructed to send samples and descriptions of the products of different regions, to identify products for trading. For example, Francis Fetiplace and Robert Hughes wrote of Robert Young - instructed to oversee the trade of indigo calicoes in Agra -

We have sent your worships by Robert Young musters of such sorts of cloths as are to be had in Agra in quantities, viz., six sorts, and are twelve pieces. The sorts are numbered from A to F, with their contents, names and prices written on their papers, and are bound and sealed up in six bundles. ${ }^{69}$

While such exchanges were arguably intended for commercial purposes, the samples and descriptions sent from India to England played an important role in acclimatising the English tastemakers with calicoes and the possibilities regarding their printing. In the earlier decades of England's trade in calico, these material objects such as samples and fabrics imported from India helped with the acclimatisation of the European consumers and merchants with cotton as a material, and more importantly with the colour-fast qualities of the fabric. Largely unintentionally, these samples as well as the EEIC men carrying or dealing with them became carriers of tacit knowledge, which provided Britain's textile industry with an epistemic design base on which to build a new commercial product. Collected for mercantile purposes, the propositional knowledge carried through the EEIC men and their samples would have rarely added to the collective or individual instructional base regarding calico printing.

\footnotetext{
${ }^{66}$ Mokyr, Gifts of Athena, 30.

${ }^{67} \mathrm{BL}$, Surat records, IOR/G/36.

${ }^{68}$ Chaudhuri, Trading World of Asia, 280.

${ }^{69}$ William Foster (ed.), Letters Received by the East India Company From its Servants in the East, vol VI, (London 1617), 249.
} 
Apart from fabric musters and instructions, the proximity of the EEIC's men in India to the production centres of calico also lead to additions in tacit knowledge concerning calico production and trade. Proximity to and interaction with the manufacturers of calico textiles could have led to the EEIC men becoming live carriers of knowledge, acquiring information through observation and communication. Probably the most extensive form of tacit transfer, unfortunately this has little to no surviving codified evidence. Mokyr states that this form of useful knowledge is also easily lost if the carriers do not communicate and transfer the knowledge. ${ }^{70}$

It should be that communication between the calico manufacturers and European traders would have been sporadic due to language inconsistencies and middlemen such as brokers. The brokers were Indian merchants, either employed by the EEIC or self-employed, who acted as the link between the factors in India and the artisans. These men were responsible for collecting orders and payments from the factors and conducting the production in time for the fabrics to be delivered to the company factories. ${ }^{71}$ The company records mention several instances where the relations between the brokers and the company officials were tumultuous, indicating that the communication of the factors beyond the brokers was rare. ${ }^{72}$ Nevertheless, through company records and proximity of the subordinate EEIC factories in relation to calico production centres in India, we can see that there was at least some level of communication between the company men and the Indian manufacturers and brokers.

Through the seventeenth and eighteenth century, the EEIC established factories in India intended as centres for trade and collection of various commercial goods. The main factories were established at Surat, Bombay [now Mumbai], Madras and Calcutta [now Kolkata] - all of which were major ports and allowed for easy maritime trade. The subordinate factories, however, were established either along overland trade routes within the subcontinent, or near production centres to allow for supervision and quality control. Francis Hastings - a company man assigned to inspect Barampore for trade goods and production - wrote to Thomas Pitt, the governor at the Madras factory in 1709, 'Barampore is a day's journey from this place affords abundance of weavers and holds very considerable merchants [...] I don't doubt your honour will find it for the company's advantage to send every year a person hither to make an involvement in longcloth, palampores [...]. ${ }^{73}$ Similarly, the company instructed the council at Madras in 1741, 'on an invitation to settle at a port opened north of Vizagapatam send a person to enquire if proper sorts of cloth were made there'. ${ }^{74}$ These examples indicate that the EEIC was keen on establishing contact with some production centres in order to eliminate middlemen, cost of transport, and irregularities in product quality.

The company was not completely successful in eliminating the Indian merchants who acted as brokers, and for various reasons they remained essential to the working of the EEIC. ${ }^{75}$ However, either accidently or due to circumstances, they maintained occasional contact with the manufacturers, and in a few cases were also instructed to deal directly with the producers. ${ }^{76}$ The council at Madras noted in 1745 that the factors settled in Maddapollam and

\footnotetext{
${ }^{70}$ Mokyr, Gifts of Athena, 9.

${ }^{71}$ Irwin, Indo-European Textile History, 13.

72 Chaudhuri, Trading World of Asia, 306.

73 Thomas Pitt's Correspondence, MS 59481, 30.

${ }^{74}$ BL, Miscellaneous Factory Records, IOR/G/40/7A.

${ }^{75}$ Chaudhuri, Trading World of Asia, 304.

${ }^{76}$ Chaudhuri, 305.
} 
Vizagpatam had no protection or subordinate brokers and had to consequently procure goods themselves from the manufacturers. ${ }^{77}$ This contact, although undesirable and a result of the shortage of company's resources and regional civil unrest, could have created direct exchange of prescriptive knowledge between the factors and the manufacturers.

Mapping of production centres of textiles in India with the EEIC's factories suggests that the factories were often either overlapping with the production centres or commercial ports. As Chaudhuri suggests, while the EEIC was not establishing centres of production, they were assessing existing centres for merits and advantages. ${ }^{78}$ This resulted in the establishment and abandonment of several subordinate factories as the production centres shifted over time due to civil unrest and natural causes. The continuous flux of movement and establishment of the new factories indicates a continuing discussion surrounding the commercial merits of calico, standardisation, finishing and design qualities which would have undoubtedly led to an increase in Britain's awareness surrounding calico. For instance, Charles Lokyer - who compiled a trade manual in 1711 - mentions that the factories at Metchlepatam, Vizagapatam, and Maddapollam along the Coromandel Coast near Madras were established for continued access to cotton and redwood manufacturers present there. ${ }^{79}$ In addition to the knowledge exchange through proximity, personal correspondence of the EEIC men and travellers in India contains some information about calico. While there is no known record that establishes codified information collected by the EEIC for the purpose of transferring printing and painting techniques within this time period, experiential records can show examples of transfer of tacit knowledge. Thomas Pitt said in a letter to London in 1700,

I have with all diligence encouraged the painting trade, and have been at some charge to do it. Without any manner partiality I think we far outdo Masulipatam and hope by the next ship to send you a thousand pieces such as never were seen in the world, if I can but keep these cursed fellows from mixing the Southern Chay [material used for red dye] with the Northern, the latter being the best and costs much more. ${ }^{80}$

Here he was presumably talking about the cotton printers that were encouraged to settle at Fort St George, the Company factory at Madras. His statement about the quality of the fabric being painted indicates his awareness regarding the raw materials, the application process, and its implications in the quality of product.

Inviting painters to Fort St George in the seventeenth century was not the only time that the EEIC attempted to solve local issues and implement standardisation by creating production centres. Chaudhuri writes of the situation in Surat in 1734 when the company's brokers complained of the weaver's instability due to unrest in the region, and consequently the weavers were invited to the company's factory in Bombay to set up production. ${ }^{81}$ The Surat factory records from 1647 also mention a dyeing house established within the factory, with 36 vats dedicated for the purpose of dyeing calicoes for export to Britain. ${ }^{82}$ These instances of contact with skilled workers in the factories of the EIC did not produce any codified manuals

\footnotetext{
77 'Relating to the method of providing callicoes on the coast of coromandel and the nature of the settlement there.' Memoranda of Correspondence, Vol 102, 1745.

${ }^{78}$ Chaudhuri, Trading World of Asia, 239-240.

${ }^{79}$ Charles Lokyer, An Account of Trade in India, (London 1711), 13.

${ }^{80}$ Letter from Thomas Pitt, British Museum MS. 22842, f. 31, quoted in Irwin, 'Indian Textile Trade in the Seventeenth Century $\{1\}$ '.

${ }^{81}$ Chaudhuri, Trading World of Asia, 251.

${ }^{82}$ BL, Surat Factory Records, Vol. 102A, 121.
} 
for the techniques employed, but the observation and communication between manufacturers and factors in the establishments certainly gives us grounds to assume that there would be some extent of tacit transfer.

Institutionally, the EEIC continued to be embroiled in political, commercial and military matters throughout the eighteenth century. The competition it faced from the New East India company from the 1689 to 1709 , reduction in its role as financial creditor to the government due to the establishment of the Bank of England in 1694, rivalry from the other trading companies and wars within Europe which often extended strategically and militarily to India - constituted issues that might have shifted the company's goals from accumulation of manufacturing knowledge. ${ }^{83}$ Nevertheless, it is crucial to recognise the role of the Indian artisan's knowledge through a decentralised approach to the global chintz network. Such histories return agency to the colonised culture, attributing intellectual contributions to India.

\section{Bibliography}

- Abu-Lughod, Janet. Before European Hegemony: The World System A.D. 1250-1350. Oxford: Oxford University Press, 1991.

- British Library, 'Relating to the method of providing callicoes on the coast of coromandel and the nature of the settlement there.' Memoranda of Correspondence, Vol 102, 1745.

- British Library, Miscellaneous Factory Records, IOR/G/40/7A.

- British Library, Surat Factory Records, Vol. 102A, 121.

- British Library, Surat records, IOR/G/36.

- British Library, Thomas Pitt's Correspondence, MS 59481.

- Capey, Reco. The Printing of Textiles. London: Chapman and Hall, 1930.

- Chapman, S.D. 'The Textile Factory Before Arkwright: A Typology of Factory Development.' The Business History Review, vol. 48, (1974), 451 - 478.

- Chapman, S.D. and S. Chassagne. European Textile Printers in the Eighteenth Century: A Study of Peel and Oberkampf. London: Heinemann Educational: Pasold Fund, 1981.

- Chaudhuri, K.N. The Trading World of Asia and the East India Company, 1660-1760. Cambridge: Cambridge University Press, 2006.

- Coleman, D.C. 'Mercantilism Revisited,' The Historical Journal, No. 23, Vol. 4, December 1980, 773-791.

- Edward Bancroft. Experimental Researches Concerning the Philosophy of Permanent Colours, and the Best Means of Producing them by Dyeing, Calico Printing etc (London: 1794).

- Epstein, S.R. 'Transfer of Technical Knowledge and Innovating in Europe,' in Technology, Skills and the Pre-Modern Economy in the East and the West, eds. Maarten Prak, Jan Luiten van Zanden, Leiden: Brill Publishing, 2013.

- Floud, C. 'The English Contribution to the Development of Copper Plate Printing,' Journal of the Society of Dyers and Colourists, (July 1960).

- Floud, C. 'The Origins of English Calico Printing,' Journal of the Society of Dyers and Colourists (June 1960).

- Floud, C. 'The English Contribution to the Early History of Indigo Printing,' Journal of the Society of Dyers and Colourists (June 1960).

\footnotetext{
${ }^{83}$ Sutherland, The East India Company, 26.
} 
- Foster, William (ed.). Letters Received by the East India Company From its Servants in the East, vol VI, (London: 1617).

- Fox, Robert and Agusti Nieto-Galan (eds.). Natural Dyestuffs and Industrial Culture in Europe, 1750-1880. Massachusetts: Science and History Publications, 1999.

- Gottmann, Felicia. Global Trade, Smuggling, and the Making of Economic Liberalism: Asian Textiles in France 1680-1760. New York: Palgrave Macmillan, 2016.

- Hilaire-Pérez, Liliane. 'Technical Invention and Institutional Credit in France and Britain in the 18th century,' History and Technology, an International Journal, vol. 16, issue 3, (2000), 285-306.

- Irwin, John and R. Schwartz. Studies in Indo-European Textile History. Ahmedabad: Calico Museum of Textile, 1966.

- Irwin, John. 'Origins of the Oriental Style in English Decorative Art.' The Burlington Magazine. vol. 97, (April 1955), 106-114.

- Landes, David S. The Wealth and Poverty of Nations: Why Some Are So Rich and Some So Poor. New York, Little, Brown, 1998.

- Lemiré, Beverly. 'Revisiting the Historical Narrative: India, Europe and the Cotton Trade, 1300-1800,' The Spinning World: A Global History of Cotton Textiles, 12001850. eds. Giorgio Riello, Prasannan Parthasarathi. Oxford: Oxford University Press, 2009.

- Lemiré, Beverly. Fashion's Favourite: The Cotton Trade and the Consumer in Britain, 1660-1800. Oxford: Oxford University Press, 1991.

- Lokyer, Charles. An Account of Trade in India, (London: 1711).

- Longfield, Ada K. 'History of the Irish Linen and Cotton Printing Industry in the 18th Century,' The Journal of the Royal Society of Antiquaries of Ireland. vol. 7, No. 1, (Jun. 30, 1937), 26-56.

- Mokyr, Joel. The Gifts of Athena: Historical Origins of the Knowledge Economy. Princeton University Press, 2002.

- O’Brien, Patrick. Trevor Griffiths, Philip Hunt, 'Political Components of the Industrial Revolution: Parliament and the English Cotton Textile Industry, 16601774,' The Economic History Review, Vol. 44, (No. 3, August 1991), 395-423.

- Ovington, John. A Voyage to Surat in the Year 1689, ed. H.G. Rawlingson. London: Oxford University Press, 1929.

- Parnell, Edward Andrew. Dyeing and Calico Printing. London, 1849.

- Pincus, Steve. 'Rethinking Mercantilism: Political Economy, the British Empire, and the Atlantic World in the Seventeenth and Eighteenth Centuries,' The William and Mary Quarterly, vol. 69, No. 1, (January 2012), 3-34.

- Pomeranz, Kenneth. The Great Divergence: China, Europe, and the Making of the Modern World Economy. Princeton: Princeton University Press, 2001.

- Riello, Giorgio. 'The Indian Apprenticeship: The Trade of Indian Textiles and the Making of European Cottons,' in How India Clothed the World: The World of South Asian Textiles, 1500-1800. Eds. Giorgio Riello, Tirthankar Roy. Leiden: Brill Publishing, 2009.

- Riello, Giorgio. 'Asian Knowledge and the Development of Calico Printing in Europe in the seventeenth and eighteenth centuries', Journal of Global History, vol. 5, (2010), 1-28.

- Riello, Giorgio. The Rise of Calico Printing in Europe and the Influence of Asia in the Seventeenth and Eighteenth Centuries. http://www.lse.ac.uk/Economic- 
History/Assets/Documents/Research/GEHN/LesTreilles/PUNERiello.pdf [accessed 25 May 2018].

- Riello, Giorgio. Cotton: The Fabric that made the Modern World. Cambridge: Cambridge University Press, 2015.

- Riello, Giorgio. 'The Globalization of Cotton Textiles: Indian Cotton, Europe and the Atlantic World, 1600-1850,' Giorgio Riello and Prasannan Parthasarathi (Eds.). The Spinning World: A Global History of Cotton Textiles, 1200-1850. Oxford: Oxford University Press, 2009, 261-87.

- Roy, Tirthankar. 'Knowledge and Divergence from the Perspective of Early Modern India,' Journal of Global History, Vol.3, (2008), 361-387.

- Schwartz, P.R. 'French Documents on Indian Cotton Painting, 1: the Beaulieu ms, c. 1734,' Journal of Indian Textile History (Vol 2, 1956).

- Shovlin, John. 'Emulation in Eighteenth-Century French Economic Thought,' Eighteenth-Century Studies, vol. 36, No. 2, (Winter 2003), 224-230.

- Styles, John. 'Indian Cottons and European Fashion, 1400-1800,' and Prasannan Parthasarathi's response in Global Design History, eds. Giorgio Riello, Sarah Teasley and Glenn Adamson. London: Taylor and Francis, 2011.

- Styles, John. The Dress of the People: Everyday Fashion in Eighteenth-century England. New Haven: Yale University Press, 2007.

- Sutherland, Lucy S. The East India Company in Eighteenth Century politics. Oxford: Clarendon Press, 1952.

- Turnbull, Geoffrey. A History of the Calico Printing Industry. London: John Sherratt and Son, 1951. 